\title{
Some Features of Campylobacter sputorum subsp. mucosalis subsp. nov., nom. rev. and Their Taxonomic Significance
}

\author{
G. H. K. LAWSON, ${ }^{1}$ J. L. LEAVER, ${ }^{2}$ G. W. PETTIGREW, ${ }^{2}$ and A. C. ROWLAND \\ Departments of Veterinary Pathology and Biochemistry, ${ }^{2}$ Royal (Dick) School of Veterinary Studies, \\ Edinburgh University, Edinburgh, Scotland
}

\begin{abstract}
We studied strains of "Campylobacter sputorum subsp. mucosalis" isolated from intestinal adenomatosis from several sources. Our results supported the contention that this organism should be regarded as a distinct subspecies of Campylobacter sputorum. However, since the name of this organism was not included on the Approved Lists of Bacterial Names, we propose it as a revived name (i.e., Campylobacter sputorum subsp. mucosalis subsp. nov., nom. rev.). The type strain is FS253/72 (= NCTC 11000). The guanine-plus-cytosine content of the deoxyribonucleic acid of this organism supports its inclusion within the genus Campylobacter, but in its hydrogen dependence this organism shows clear similarities to the human oral vibrios and to Vibrio succinogenes. However, " $C$. sputorum subsp. mucosalis" possesses an unusual type $c$ cytochrome, and in this way it appears to differ from $V$. succinogenes. It may be differentiated readily from other members of the species $C$. sputorum by salt and glycine tolerance tests or by serological techniques.
\end{abstract}

At one time, the microaerophilic vibrios and the aerobic glucose-fermenting vibrios were included in a single genus, Vibrio. Later, these two groups of organisms were separated, and the microaerophilic organisms were placed in a different genus, Campylobacter (1). Broadly, this latter genus was divided into two main groups, the catalase-positive organisms associated with animal and human diseases and a single catalase-negative species, Campylobacter sputorum; within the species $C$. sputorum two subspecies were recognized, $C$. sputorum subsp. sputorum from the human gingival margin and C. sputorum subsp. bubulus, a commensal from the bovine genital tract. Often catalase-negative, microaerophilic vibrio can be recovered in very large numbers from the lesions of porcine intestinal adenomatosis. This organism shares many features with the two named subspecies of $C$. sputorum but can be distinguished from them, and on this basis the name "Campylobacter sputorum subsp. mucosalis" was proposed by Lawson and Rowland (5). This organism may have a particular relevance to the lesions of adenomatosis, as an intracellular vibrio-shaped bacterium has been observed lying free in the apical cytoplasm of intestinal cells in lesions of this disease (13).

The initial descriptions of " $C$. sputorum subsp. mucosalis" were based on relatively few strains, and therefore it was desirable to study more strains in order to define the taxon better and more fully. Although validly published (7), the name "C. sputorum subsp. mucosalis" did not appear on the Approved Lists of Bacterial Names (14), and therefore it has no standing in nomenclature. (Names in quotation marks are not on the Approved Lists.) In this paper we provide a more comprehensive description of this organism and revive the name C. sputorum subsp. mucosalis, thereby giving it standing in nomenclature.

\section{MATERIALS AND METHODS}

Bacterial strains. The $C$. sputorum strains which we studied included some previously described strains $(6,7)$ and some recently isolated strains. We isolated the majority of the "C. sputorum subsp. mucosalis" strains from cases of intestinal adenomatosis. We also studied strains from similar pathological material from the sources listed in Table 1.

Characterization tests and serology. The tests used for hydrogen sulfide and catalase production, nitrate and nitrite reduction, and growth in the presence of glycine, sodium chloride, and deoxycholate have been described previously $(6,7)$. Antisera were obtained from rabbits, and agglutination tests were carried out with serovar (serotype) A strain 1, serovar B strain 23 , and an additional strain (strain 41 ), designated serovar $\mathrm{C}$; these tests were performed by previously described methods (5).

Tests for growth in gaseous environments. The hydrogen microaerophilic atmosphere used (5) contained $77 \%$ hydrogen, $10 \%$ nitrogen, $3 \%$ oxygen, and $10 \% \mathrm{CO}_{2}$. An additional gaseous environment used was prepared in a similar way except that nitrogen replaced the hydrogen; this atmosphere contained $87 \%$ nitrogen, $3 \%$ oxygen, and $10 \% \mathrm{CO}_{2}$. Replicate plates 


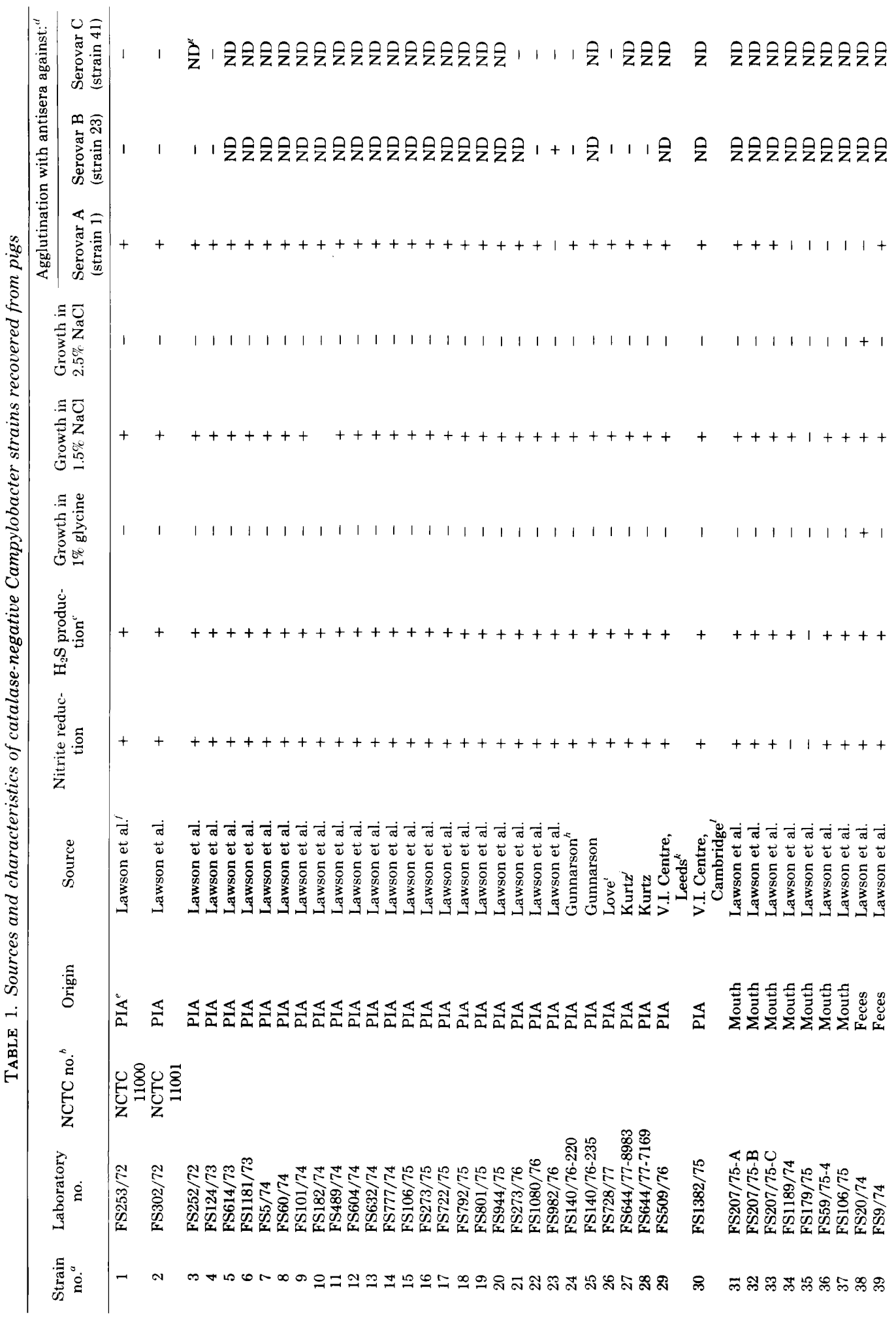




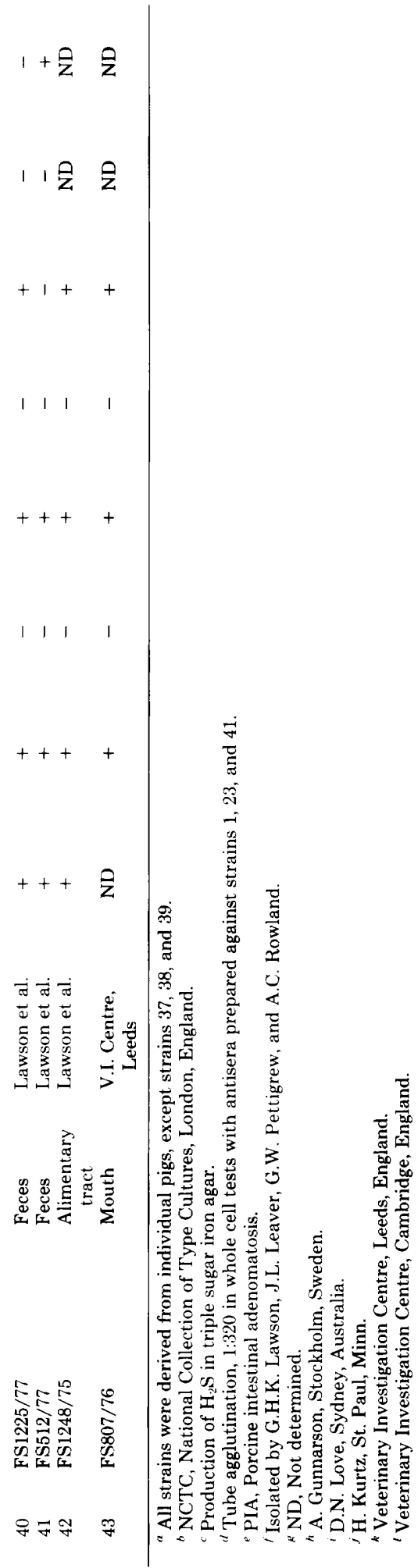

containing Hartley digest blood agar were prepared by a previously described method (7), and these plates were incubated in the two atmospheres at $37^{\circ} \mathrm{C}$. Because the imprint of the velour pad used to inoculate the plates made it difficult to detect small surface colonies, tests were repeated with plates inoculated conventionally with a loop. Tests were read after 24 , 48 , and $72 \mathrm{~h}$, and the jars were regassed daily.

Tests for growth in solid media containing sodium formate. Organisms were grown in diphasic media (Columbia blood agar slope [type CM 331; Oxoid Ltd., London, England] with a tryptose phosphate broth overlay [type CM 283; Oxoid]) for $18 \mathrm{~h}$ at $37^{\circ} \mathrm{C}$ in a hydrogen microaerophilic atmosphere. The supernatant was diluted $1: 100$ in $0.1 \mathrm{M}$ phosphatebuffered saline $(\mathrm{pH} \mathrm{7.4)}$, and $0.01 \mathrm{ml}$ of the diluted culture was used to inoculate each blood agar (type CM 271; Oxoid) plate containing $5 \%$ horse blood and $2.5 \mathrm{mg}$ of sodium formate per $\mathrm{ml}$.

Growth of "C. sputorum subsp. mucosalis" for determination of DNA base composition. To determine the deoxyribonucleic acid (DNA) base composition, strain 1 was grown under microaerophilic conditions at $37^{\circ} \mathrm{C}$ for $48 \mathrm{~h}$ on Hartley digest blood agar. The surface growth was removed and was suspended in $0.01 \mathrm{M}$ phosphate-buffered saline ( $\mathrm{pH} 7.2$ ). The bacteria were recovered by centrifugation at 4,000 rpm for $20 \mathrm{~min}$, and the wet weight was obtained. Preparations of Escherichia coli FS 460/67 and Proteus vulgaris OX19 strain NCTC 8313 were obtained in a similar manner, except that incubation was for 18 $\mathrm{h}$ at $37^{\circ} \mathrm{C}$ in air. The wet bacteria were stored at $-50^{\circ} \mathrm{C}$ before analysis.

Estimation of DNA base composition. DNA was isolated from approximately $500 \mathrm{mg}$ of wet packed cells by the method of Marmur (10), except that ribonuclease preheated to $80^{\circ} \mathrm{C}$ was used at a concentration of $100 \mathrm{mg} / \mathrm{ml}$ to digest the ribonucleic acid. The final product was dissolved in $0.15 \mathrm{M} \mathrm{NaCl}-0.015$ $M$ trisodium citrate ( $\mathrm{pH} 7.0$ ) to give an absorbance at $260 \mathrm{~nm}$ of approximately 0.5. DNA purity was checked by calculating the ratio of the absorbance at $260 \mathrm{~nm}$ to the absorbance at $235 \mathrm{~nm}$; a ratio of more than 2.0 was taken as satisfactory for thermal denaturation studies. $E$. coli DNA was isolated by the same procedure and was used as a standard.

Thermal denaturation curves were determined by P.M.B. Walker of the Medical Research Council Mammalian Genome Unit, Department of Zoology, University of Edinburgh. The base composition of the DNA was calculated from the following formula, which was applicable to a solvent containing $0.2 \mathrm{M} \mathrm{Na}^{+}$: moles percent guanine plus cytosine $=2.44\left(T_{m}-69.3\right)$, where $T_{m}$ is the thermal denaturation temperature in degrees centigrade (11).

Growth of "C. sputorum subsp. mucosalis" for metabolic studies and for investigation of constituent cytochromes. Strain 1 was grown as described above for the DNA base composition study. The washed bacteria were suspended at a concentration of $80 \mathrm{mg}$ (wet weight) per $\mathrm{ml}$ in $0.01 \mathrm{M}$ sodium

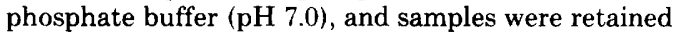
as whole cells or were sonicated for $10 \mathrm{~min}$ at an amplitude of $8 \mu \mathrm{m}$ (MSE Scientific Instruments Ltd., 
Crawley, England) on ice. Cell lysates were examined either immediately after being held at $5^{\circ} \mathrm{C}$ or after freezing at $-50^{\circ} \mathrm{C}$. A stock Pseudomonas aeruginosa strain was used to obtain cytochrome preparations for comparison.

Investigation of constituent cytochromes. A total of $14 \mathrm{ml}$ of sonic extract was centrifuged at $150,000 \times g$ for $2 \mathrm{~h}$. The resulting pellet was suspended in $2 \mathrm{ml}$ of water, and both this suspension and the supernatant were used for cytochrome characterizations.

A Unicam SP1800 spectrophotometer was used to determine the absorption characteristics of the cytochromes or their derivatives (pyridine ferrohemochromes). Difference spectra (dithionite reduced minus ferricyanide oxidized and $\mathrm{CO}$ reduced minus reduced) were obtained for samples prepared by standard procedures.

Investigation of respiratory substrates. The possible sources of reducing equivalents for strain 1 were identified in two ways. Either the ability of the substrate to reduce endogenous cytochrome was determined spectrophotometrically with the Unicam SP1800 spectrophotometer, or oxygen utilization was followed by using an oxygen electrode. To study the reduction of cytochromes, sonic extracts were equilibrated with hydrogen (for estimating reduction with hydrogen) or nitrogen (for all other possible reductants).

\section{RESULTS}

Examination of strains. A total of 43 strains of catalase-negative vibrios isolated from adenomatosis or related conditions or recovered from pigs over a period of 6 years were included in this study. All of the strains examined reduced nitrate and failed to grow in the presence of deoxycholate; other characteristics of the strains are given in Table 1 . The strains which we isolated were recovered from material obtained from eight separate pig farms, and these strains plus the strains isolated from other areas of the United Kingdom and from four continents should constitute a fair representation of the taxon.

The characteristics of the strains isolated from adenomatosis conformed to the descriptions published previously for " $C$. sputorum subsp. mucosalis." A few strains showed slight growth in some tests with $1 \%$ glycine or $0.2 \%$ deoxycholate; this growth was always minimal compared with the growth obtained with control media lacking these substances. Occasionally, recently isolated strains failed to reduce nitrite over the period of the test; this feature rarely persisted on repeated tests. Identical organisms and other similar but distinct catalase-negative vibrios could be recovered from the mouths, feces, and alimentary tracts of pigs.

Two and possibly three distinct serogroups of organisms appeared to be involved in the aden- omatosis complex; these were the commonly occurring types which reacted with antisera prepared against strain 1 serovar A organisms and the types which reacted with strain 23 or 41 antisera (serovars B and C, respectively). Confirmation that serovar $\mathrm{C}$ strains are involved in adenomatosis has yet to be obtained, as a serovar $\mathrm{C}$ strain was isolated from only the feces of a clinical case.

DNA base composition. The DNA base composition of strain 1 was $33.9 \mathrm{~mol} \%$ guanine plus cytosine, as calculated from the thermal denaturation temperature of $83.2^{\circ} \mathrm{C}$. In Table 2 these results are compared with the results obtained by other workers for members of the genus Campylobacter and related organisms.

Growth in nitrogen and hydrogen. Table 3 summarizes the growth of Campylobacter strains in the hydrogen and nitrogen microaerophilic atmospheres. Campylobacter fetus subsp. fetus strain FS461/73 grew normally in both the nitrogen and hydrogen atmospheres, whereas all of the C. sputorum strains grew well only in the hydrogen-rich atmosphere. There appeared to be small differences between the amount of growth produced by the " $C$. sputorum subsp. mucosalis" strains and the amount of growth produced by the human and pig oral strains

TABLE 2. Base compositions of DNAs of Campylobacter strains and $V$. succinogenes

\begin{tabular}{lcc}
\hline \multicolumn{1}{c}{ Organism(s) } & $\begin{array}{c}\text { Guanine-plus- } \\
\text { cytosine con- } \\
\text { tent (mol\%) }\end{array}$ & Reference \\
\hline C. fetus subsp. fetus & 34.4 & 16 \\
C. fetus subsp. venerealis & 34.4 & 16 \\
C. sputorum subsp. bubulus & 30.1 & 16 \\
Catalase-positive human oral & 49.3 & 15 \\
$\quad$ strains & 48.2 & 15 \\
Catalase-negative human oral & & 4 \\
$\quad$ strains & 49.0 & \\
V. succinogenes & 33.9 & \\
"C. sputorum subsp. & & \\
$\quad$ mucosalis" FS253/72 & & \\
(=NCTC 11000) & & \\
\hline
\end{tabular}

TABLE 3. Growth of Campylobacter species in hydrogen and nitrogen microaerophilic atmospheres

\begin{tabular}{|c|c|c|c|}
\hline \multirow{2}{*}{ Organism } & \multirow{2}{*}{$\begin{array}{l}\text { No. of } \\
\text { strains } \\
\text { tested }\end{array}$} & \multicolumn{2}{|c|}{ Growth in: } \\
\hline & & $\mathrm{H}_{2}$ & $\mathrm{~N}_{2}$ \\
\hline C. fetus subsp. fetus & 1 & +++ & +++ \\
\hline C. sputorum subsp. sputorum & 3 & +++ & - or \pm \\
\hline \multicolumn{4}{|l|}{ C. sputorum subsp. mucosalis } \\
\hline Serovar A & 14 & +++ & + or - \\
\hline Serovar B & 1 & +++ & + \\
\hline $\begin{array}{l}\text { Porcine mouth strain } \\
\text { (catalase negative; not } \\
\text { serovar } \mathrm{A} \text { or } \mathrm{B} \text { ) }\end{array}$ & 1 & +++ & - \\
\hline
\end{tabular}

${ }^{a}-$, No growth discernible; \pm , occasional, small colonies; + , some small colonies; +++ , normal colony development. 
tested. The latter strains produced little or no growth, whereas the former frequently yielded very small colonies which did not enlarge during reincubation; visualization of these fine colonies depended to some extent on the method of inoculation, and imprints in the agar surface obscured their presence. There seemed to be no evidence for any difference in the behavior between old stock cultures and recent isolates of "C. sputorum subsp. mucosalis."

Nature of cytochromes. Preliminary spectrophotometric studies of " $C$. sputorum subsp. mucosalis" showed that it contained relatively large quantities of a type $c$ cytochrome. Figure 1 shows dithionite-reduced minus ferricyanideoxidized difference spectrum of a sonicated cell suspension. This figure shows $\alpha$ and $\beta$ absorption peaks at 553 and $524 \mathrm{~nm}$, respectively. After centrifugation of this sonic extract at $150,000 \times$ $g$ for $2 \mathrm{~h}$, we determined the distribution of heme $\mathrm{C}$ and protoheme IX in the supernatant and pellet (Table 4). Heme $\mathrm{C}$, the major heme detected, was found in both the pellet and the supernatant. The combined heme $C$ content was $123 \mathrm{nmol} / 1.12 \mathrm{~g}$ (wet weight) of cells; if present in one monoheme cytochrome, this content would represent $>100 \mu \mathrm{mol}$ of cytochrome per $\mathrm{kg}$ (wet weight).

Reduced minus oxidized difference spectra of

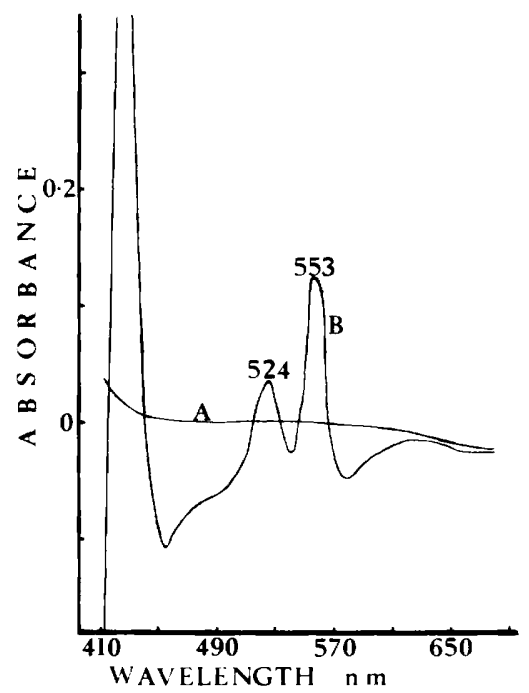

Fig. 1. Difference spectra of a "C. sputorum subsp. mucosalis" cell sonic extract. The cell sonic extract was prepared at a concentration of $80 \mathrm{mg}$ (wet weight) of cells per ml. Line A shows the base line established with the cell sonic extract in both reference and sample cuvettes. Line $B$ shows the results when the reference solution was oxidized with potassium ferricyanide and the sample solution was reduced with sodium dithionite. both the suspended pellet and the supernatant also showed the presence of the type $c$ cytochrome $\alpha$ absorption band at $553 \mathrm{~nm}$. Figure 2 shows absolute spectra of the supernatant. Ascorbate $(2 \mathrm{mM})$ was not effective in reducing the type $c$ cytochrome, which suggests that the midpoint oxidation reduction potential had a negative value; i.e., it was comparatively low for a type $c$ cytochrome.

The reduced minus oxidized difference spectrum of a sonicated cell suspension (Fig. 1) also showed a weak, broad band at $620 \mathrm{~nm}$. Carbon monoxide reduced minus reduced difference spectra showed a small but definite peak at 630 $\mathrm{nm}$. These results suggested that a type $d$ cytochrome may have been present. However, we

TABLE 4. Distribution of heme after centrifugation of cell sonic extract ${ }^{a}$

\begin{tabular}{ccc}
\hline \multirow{2}{*}{ Heme } & \multicolumn{2}{c}{ Amt (nmol) in: } \\
\cline { 2 - 3 } & Pellet & Supernatant \\
\hline Heme C & 42 & 81 \\
Protoheme IX & 6 \\
\hline
\end{tabular}

${ }^{a}$ A total of $14 \mathrm{ml}$ of a suspension containing $80 \mathrm{mg}$ (wet weight) of cells per $\mathrm{ml}$ was sonicated and centrifuged at $150,000 \times g$ for $2 \mathrm{~h}$. Protoheme IX in the suspended pellet and protoheme IX in the supernatant were extracted into $1 \% \mathrm{HCl}$ in acetone, and their amounts were determined as pyridine ferrohemochrome (maximum, $557 \mathrm{~nm}$ ). Heme $\mathrm{C}$ is not extracted into acid-acetone, and the amount of heme $\mathrm{C}$ was also determined as pyridine ferrohemochrome (maximum, $550 \mathrm{~nm}$ ).

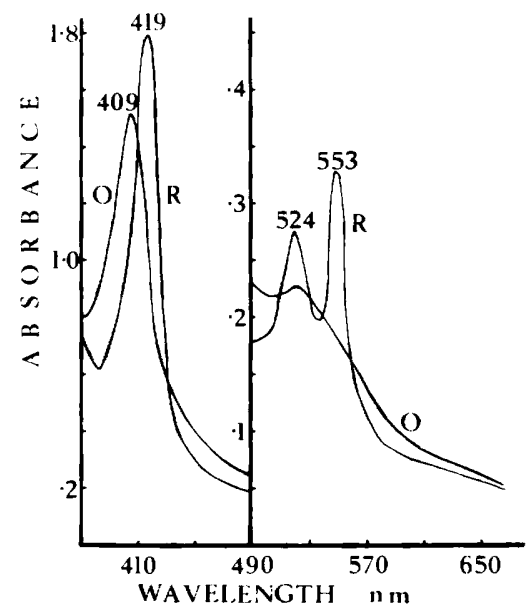

FIG. 2. Absolute spectra of "C. sputorum subsp. mucosalis" cytochrome $c_{553}$. A cell sonic extract $(80$ $\mathrm{mg}$ [wet weight] of cells per $\mathrm{ml}$ ) was centrifuged at $150,000 \times g$ for $2 \mathrm{~h}$. The dithionite-reduced (line $R$ ) and ferricyanide-oxidized (line $O$ ) spectra were recorded by using the clear supernatant. 
were not able to detect any type $d$ heme in acidacetone extracts.

Respiratory substrates. The endogenous cytochrome $c_{553}$ of " $C$. sputorum subsp. mucos alis" (1) was reduced rapidly when cell suspensions or sonic extracts were supplied with either hydrogen or formate. Lactate, succinate, and reduced nicotinamide adenine dinucleotide gave slight reductions, and methanol, formaldehyde, malate, glutamate, and serine were inactive. On exposure to air, the hydrogen- or formate-reduced cytochrome was reoxidized rapidly, and this reoxidation was not affected by cyanide up to a concentration of $3 \mathrm{mM}$.

In the oxygen utilization experiments with the oxygen electrode, sonic extracts and cell suspensions gave similar results, and once again the same substrates (hydrogen, formate and, to a small extent, reduced nicotinamide adenine dinucleotide and succinate) favored the utilization of oxygen. This reaction was insensitive to cyanide $(0.4 \mathrm{mM})$. Glutamate, lactate, malate, glycerol, glucose, glucose 6-phosphate, and glycerol phosphate were inactive as respiratory substrates.

Growth in the presence of sodium formate. Plates containing sodium formate in a nitrogen atmosphere supported the growth of 13 of 14 strains of " $C$. sputorum subsp. mucosalis" serovars $A$ and $B$ at a level comparable to the level obtained with the same basal media in a hydrogen atmosphere. However, one strain (strain 27) grew only poorly under formate-nitrogen conditions.

Fluid media. "C. sputorum subsp. mucosalis" grows poorly in most conventional fluid media and requires a hydrogen microaerophilic atmosphere in addition to an agar slant with a broth overlay to provide satisfactory fluid phase growth. Our results suggested a solution to this problem, and we obtained satisfactory growth of the six strains tested (strains 1, 2, 4, 26, 27, and 28 ) in a fluid medium containing $2.5 \mathrm{~g}$ of sodium chloride, $7.5 \mathrm{~g}$ of proteose peptone (type L46; Oxoid) $1.25 \mathrm{~g}$ of liver digest (type L27; Oxoid) $2.5 \mathrm{~g}$ of yeast extract (Difco Laboratories), 1.25 $\mathrm{g}$ of sodium formate, and distilled water to 500 $\mathrm{ml}$. The ingredients were dissolved by heating the preparation to $56^{\circ} \mathrm{C}$; the solution was then cooled, and the $\mathrm{pH}$ was adjusted to 7.4 with 1.0 $\mathrm{N} \mathrm{NaOH}$. Containers filled with $5 \mathrm{ml}$ of this medium were autoclaved at $15 \mathrm{lb} / \mathrm{in}^{2}$ for $15 \mathrm{~min}$ with the caps loose; after autoclaving, the caps were tightened while they were hot, and when the medium was cool, $0.1 \mathrm{ml}$ of inactivated rabbit serum (Wellcome Research Laboratories) was added to each $5 \mathrm{ml}$ of medium. Such media could be inoculated and incubated without any special atmospheric precautions.

\section{DISCUSSION}

An examination of " $C$. sputorum subsp. mucosalis" strains derived from a variety of sources indicated that this taxon is homogeneous and that strain FS253/72 (=NCTC 11000) is representative of this group. The taxonomic positions of the other biochemically and serologically distinct catalase-negative vibrios isolated from pigs are less certain. We are in favor of retaining the name " $C$. sputorum subsp. mucosalis" for those organisms that can be demonstrated within the cells of adenomatosis lesions and for bacteria that cannot be distinguished from these organisms. Consequently, we propose that the name Campylobacter sputorum subsp. mucosalis be revived for the same organism with which the name was associated when it was published originally by Lawson et al. $(5,7)$. The type strain is FS253/72 (=NCTC 11000). The separation of $C$. sputorum subsp. mucosalis from C. sputorum subsp. sputorum and $C$. sputorum subsp. bubulus can be achieved in the laboratory in most instances relatively easily by salt or glycine tolerance tests or by serological means (7). C. sputorum subsp. bubulus is glycine and salt tolerant, and $C$. sputorum subsp. sputorum is glycine tolerant, whereas " $C$. sputorum subsp. mucosalis" does not grow in $1 \%$ glycine but does grow in salt concentrations similar to those in which C. sputorum subsp. sputorum grows. Serological cross-reactions among these subspecies have not been reported.

The taxonomic positions of the human oral vibrios and of $V$. succinogenes are uncertain. The guanine-plus-cytosine contents of the DNAs of the oral vibrios and of $V$. succinogenes are between 48 and $50 \mathrm{~mol} \%(15,17)$; this should exclude them from the genus Campylobacter, in which guanine-plus-cytosine contents are between 30 and $35 \mathrm{~mol} \%$ (1). The guanine-pluscytosine contents of strains of oral vibrios originally identified as $C$. sputorum subsp. sputorum (9) have not been determined.

During its phase of intracellular parasitism, $C$. sputorum subsp. mucosalis is thought to multiply primarily within cells. Ultrastructural studies of the parasitized mucosa fail to show a bacterial population outside and adjacent to the infected cells, and profiles of dividing bacteria can be seen within the cell cytoplasm (6). Presumably, the energy necessary for such bacterial multiplication is derived from the host cells, and an understanding of this relationship may indicate how the bacteria influence a parasitized cell. It is believed that hydrogen is produced within the alimentary tract in humans at levels which are detectable in breath. The increase in respiratory hydrogen levels after eating indicates 
that the lower ileum may be the site of origin of this gas (2). At the moment, whether hydrogen acts as an important electron donor during the intracellular growth of $C$. sputorum subsp. mucosalis is highly speculative. C. sputorum subsp. mucosalis can become established in the oral cavity, a site at which hydrogen is likely to be considerably less abundant, except possibly in microclimates. This organism also becomes established in gnotobiotic piglets monocontaminated only by members of the genus Bacillus and can survive in the presence of tissue culture systems in which hydrogen enrichment of the gaseous phase is not used. Both nitrate and nitrite are reduced by $C$. sputorum subsp. $m u$ cosalis, and in this way this organism seems to be similar to $V$. succinogenes, which can grow in a medium in which formate and nitrate are the sole energy sources.

Cytochrome $c_{553}$ has been identified as the major cytochrome of C. sputorum subsp. mucosalis. The reducibility of this cytochrome by formate suggests that it may act in an electron transport chain concerned with formate oxidation that is similar to the chain present in other organisms (8). However, in $E$. coli and $V$. succinogenes the electron acceptor for formate dehydrogenase is a type $b$ cytochrome rather than a type $c$ cytochrome (3), and indeed rather few low-spin type $c$ cytochromes are known that have redox potentials comparable to those found in type $b$ cytochromes (12). The best-characterized low-spin, low-potential, type $c$ cytochrome is cytochrome $c_{3}$ of the sulfate-reducing bacteria. However, C. sputorum subsp. mucosalis cytochrome $c_{553}$ is spectroscopically distinct from these cytochromes in that it has a relatively low soret reduced/soret oxidized spectroscopic ratio and no indication of a weak shoulder to the short wavelength side of the soret reduced peak (Fig. 2).

A further comparison of the C. sputorum subsp. mucosalis cytochrome with other type $c$ cytochromes (such as the low-potential cytochrome $c_{553}$ found in some sulfate-reducing bacteria) would be premature and must await the purification of this cytochrome.

\section{REPRINT REQUESTS}

Address reprint requests to: Dr. G. H. K. Lawson, Depart- ment of Veterinary Pathology, Veterinary Field Station, Easter Bush, Roslin, Midlothian, Scotland.

\section{LITERATURE CITED}

1. Buchanan, R. E., and N. E. Gibbons (ed.). 1974. Bergey's manual of determinative bacteriology, 8 th ed. The Williams \& Wilkins Co., Baltimore.

2. Calloway, D. H. 1966. Respiratory hydrogen and methane as affected by consumption of gas-forming foods. Gastroenterology 51:383-389.

3. Haddock, B. A., and C. W. Jones. 1977. Bacterial respiration. Bacteriol. Rev. 41:47-99.

4. Hill, L. R. 1966. An index to deoxyribonucleic acid base composition of bacterial species. J. Gen. Microbiol. 44: 419-437.

5. Lawson, G. H. K., and A. C. Rowland. 1974. Intestina adenomatosis in the pig: a bacteriological study. Res. Vet. Sci. 17:331-336.

6. Lawson, G. H. K., A. C. Rowland, and L. Roberts. 1976. Studies on Campylobacter sputorum subspecies mucosalis. J. Med. Microbiol. 9:163-171.

7. Lawson, G. H. K., A. C. Rowland, and P. Wooding. 1975. The characterization of Campylobacter sputorum subspecies mucosalis isolated from pigs. Res. Vet. Sci. 18: $121-126$.

8. Le Gall, J., and J. R. Postgate. 1973. The physiology of sulphate-reducing bacteria. Adv. Microb. Physiol. 10: 81-133.

9. Loesche, W. J., R. J. Gibbons, and S. S. Socransky. 1965. Biochemical characteristics of Vibrio sputorum and its relationship to Vibrio bubulus and Vibrio fetus. J. Bacteriol. 89:1109-1116.

10. Marmur, J. 1961. A procedure for the isolation of deoxyribonucleic acid from micro-organisms. J. Mol. Biol. 3: 208-218.

11. Marmur, J., and P. Doty. 1962. Determination of the base composition of deoxyribonucleic acid from its thermal denaturation temperature. J. Mol. Biol. 5:109-118.

12. Pettigrew, G. W. 1981. Bacterial cytochromes. Patterns of Progress Microbiology Series. Meadowfield Press, Durham, England.

13. Rowland, A. C., and G. H. K. Lawson. 1974. Intestinal adenomatosis in the pig: immunofluorescent and electron microscopic studies. Res. Vet. Sci. 17:323-330.

14. Skerman, V. B. D., V. McGowan, and P. H. A. Sneath (ed.). 1980. Approved lists of bacterial names. Int. J. Syst. Bacteriol. 30:225-420.

15. van Palenstein, W., W. H. Helderman, and I. Rosman. 1976. Hydrogen-dependent organisms from the human gingival crevice resembling Vibrio succinogenes. Antonie van Leeuwenhoek J. Microbiol. Serol. 42:107-118.

16. Véron, M., and R. Chatelain. 1973. Taxonomic study of the genus Campylobacter Sebald and Veron and designation of the neotype strain for the type species, Campylobacter fetus. Int. J. Syst. Bacteriol. 23:122134.

17. Wolin, M. J., E. A. Wolin, and N. J. Jacobs. 1961 Cytochrome-producing anaerobic vibrio, Vibrio succin. ogenes. J. Bacteriol. 81:911-917. 